\title{
Influence of insulin antibodies on pharmacokinetics and bioavailability of recombinant human and highly purified beef insulins in insulin dependent diabetics
}

\author{
R S GRAY, P COWAN, U DI MARIO, R A ELTON, B F CLARKE, L J P DUNCAN
}

\begin{abstract}
Sixteen insulin dependent diabetics of long standing, with undetectable fasting plasma $C$ peptide concentrations, and eight non-diabetic controls were each infused intravenously with biosynthetic human and highly purified beef insulin (1 $\mathrm{mU} / \mathrm{kg} / \mathrm{min}$ ) while euglycaemia was maintained by a Biostator. No difference was observed between the two insulins in respect of insulin pharmacokinetics or biological action. The diabetics showed appreciable insulin resistance, manifested by a $40 \%$ reduction in the rate of insulin mediated glucose disposal, which was unrelated to the presence of insulin antibodies. Insulin binding antibodies, however, increased insulin's clearance rate and distribution space and prolonged its pharmacological and biological half lives. The rate at which insulin action was lost, after an intravenous infusion, was more rapid in diabetics without insulin antibody binding than in controls.

In respect of their influence on insulin pharmacokinetics, moderate concentrations of insulin antibodies may be of positive advantage to all diabetics without endogenous insulin secretion and are not responsible for the insulin resistance of type 1 diabetes.
\end{abstract}

\footnotetext{
Diabetic and Dietetic Outpatient Department, Royal Infirmary, Edinburgh EH3 9YW

R S GRAY, MD, senior registrar

P COWAN, BSC, FIMLS, research assistant

U DI MARIO, MD, assistant professor

B F CLARKE, FRCP, consultant physician

L J P DUNCAN, FRCP, consultant physician
}

Medical Computing and Statistics Unit, University of Edinburgh R A ELTON, BA, PHD, senior lecturer

Correspondence to: Dr R S Gray.

\section{Introduction}

The introduction of highly purified animal insulins and recombinant deoxyribonucleic acid (DNA) technology has led to substantial alterations in the prescribing habits of diabetologists within the United Kingdom. These changes have been largely justified on the basis that these newer insulins, being less immunogenic, albeit more expensive, are associated with lower titres of insulin antibodies. It is curious, therefore, that little is known of the influence of such antibodies on insulin action and pharmacokinetics.

The purpose of this study was to compare the bioavailability and pharmacokinetics of biosynthetic human and highly purified bovine insulins in insulin dependent diabetics and to consider the influence of insulin antibodies on insulin action.

\section{Subjects and methods}

We studied 16 patients with type 1 , insulin dependent diabetes and eight non-diabetic controls. Table 1 shows their clinical characteristics. All diabetics and controls had normal serum creatinine concentrations and normal results to liver function tests, none was anaemic, and none was taking any drug other than insulin known to influence carbohydrate metabolism.

Eight diabetics showed no ophthalmoscopic evidence of retinopathy or labstix proteinuria. Of the remaining eight diabetics, who had ophthalmoscopic diabetic retinopathy (six with background changes alone and two with neovascularisation), two had labstix proteinuria $(1+$ only). All had undetectable fasting plasma $\mathrm{C}$ peptide concentrations.

TABLE I-Clinical data of diabetics and controls

\begin{tabular}{lccccc}
\hline Subjects & $\begin{array}{c}\text { Sex ratio } \\
(\mathrm{M}: \mathrm{F})\end{array}$ & $\begin{array}{c}\text { Mean (SEM) } \\
\text { age } \\
\text { (years) }\end{array}$ & $\begin{array}{c}\text { Mean (SEM) } \\
\text { weight (kg) } \\
\text { [\%eal body } \\
\text { weight] }\end{array}$ & $\begin{array}{c}\text { Mean (SEM) } \\
\text { duration of } \\
\text { diabetes } \\
\text { (years) }\end{array}$ & $\begin{array}{c}\text { Mean (SEM) } \\
\text { daily } \\
\text { insulin } \\
\text { dose (U) }\end{array}$ \\
\hline Diabetics & $12: 4$ & $43(2)$ & $\begin{array}{c}70(2) \\
{[94(6)]}\end{array}$ & $21(2)$ & $58(4)$ \\
Controls & $5: 3$ & $38(6)$ & $\begin{array}{c}67(4) \\
{[94(4)]}\end{array}$ & & \\
\hline
\end{tabular}


At the time of the study six diabetics were receiving highly purified pork insulin and 10 conventional beef insulin. They were selected to include patients of widely varying insulin antibody binding levels. All attended the diabetic department at this hospital.

We obtained permission for this study from this hospital's physicians' advisory ethical committee and informed consent from all subjects.

We used biosynthetic human insulin prepared by a recombinant DNA technique at a concentration of $40 \mathrm{U} / \mathrm{ml}$, assayed by the United States Pharmacopeia bioassay, and bovine insulin at a concentration of $40 \mathrm{U} / \mathrm{ml}$, assayed by the British Pharmacopoeia method C. Each insulin solution was submitted to separation by high pressure liquid chromotography, and the insulin contents were compared against an insulin standard of established biological potency yielding values of 41.2 and $40.1 \mathrm{U} / \mathrm{ml}$ for bovine insulin and biosynthetic human insulin, respectively. Nitrogen contents were 0.231 and $0.245 \mathrm{mg} / \mathrm{ml}$, respectively.

Each subject was studied with biosynthetic human insulin and bovine insulin on different days separated by an interval of at least two weeks, the order having been randomised. The diabetics were converted to intermittent (three to four times daily), short acting subcutaneous insulin injections 48 hours before study. For 15 hours (overnight) before study glycaemic control was maintained by an intravenous infusion $(0 \cdot 4-1 \cdot 2 \mathrm{U} / \mathrm{h})$ of insulin, the last dose of subcutaneous short acting insulin having been received 20 hours before study. Short acting bovine insulin or biosynthetic human insulin was used according to whichever insulin was to be employed for the infusion study. Diabetics and controls fasted from 2200 on the evening before the study.

At 0800 on the morning of the study a Venflon cannula was introduced into a superficial distal forearm vein, from which a double lumen catheter continuously sampled arterialised venous blood (the forearm having been enclosed in a heating pad at $60^{\circ} \mathrm{C}$ ). The second cannula introduced into the antecubital vein of the same arm was used for blood sampling, being flushed after use with $0.9 \%$ saline. A third cannula, in the opposite antecubital vein, was used for infusion of $20 \%$ glucose, biosynthetic human insulin, or bovine insulin. The infusion catheter and continuous arterialised blood sampling cannulas were connected to a glucose controlled glucose infusion system (Biostator Controller; Life Science Instruments, Elkart, Indiana, USA) for infusion of glucose and monitoring of glucose concentrations, respectively.

The Biostator's maximum glucose infusion rate is roughly $2 \mathrm{ml} /$ min, and when the patient's glucose disposal rate approached or exceeded this value an independent additional source of $20 \%$ glucose was provided by an I-Med infusion pump, whose rate of infusion was manually controlled by the observer.

Calibration of the Biostator and achievement of stability of the glucose sensor required one hour before the insulin infusion began. Either biosynthetic human insulin or bovine insulin was then infused initially at a priming rate of $2 \mathrm{mU} / \mathrm{kg} / \mathrm{min}$ for 10 minutes (to fill the insulin's distribution space) and thereafter at $1 \mathrm{mU} / \mathrm{kg} / \mathrm{min}$. The insulin was diluted in $50 \mathrm{ml} 0.9 \%$ saline, to which $1 \mathrm{ml} 20 \%$ human serum albumin was added, and infused with a Harvard pump. Blood glucose concentration was allowed to fall to $3.9 \mathrm{mmol} / \mathrm{l}$ ( 70 $\mathrm{mg} / 100 \mathrm{ml}$ ), where it was "clamped" for two hours, the rate of the I-Med $20 \%$ glucose infusion having been adjusted to allow the Biostator to maintain euglycaemia with a glucose infusion rate of approximately $1.1 \mathrm{mmol}(200 \mathrm{mg}) / \mathrm{min}$. In each subject the clamp was maintained at the end of the $1 \mathrm{mU} / \mathrm{kg} / \mathrm{min}$ insulin infusion to measure the rate of insulin deactivation. ${ }^{1}$

The Biostator was recalibrated against two external standard glucose solutions at hourly intervals during both the insulin infusion and the study of insulin deactivation. The obligatory glucose infusion rate required to maintain euglycaemia in the face of insulin action corresponded to the glucose disposal rate. This was corrected every 10 minutes for changes in blood glucose concentration in the rapidly equilibrating glucose pool, assumed to be $137 \mathrm{ml} / \mathrm{kg}$ body weight. ${ }^{2}$

In each subject blood samples were obtained under basal conditions, at 20 minute intervals during the second euglycaemic hour of the insulin infusion, and at five, 10,15,20,30,40, and subsequently at 20 minute intervals at the end of the infusion of $1 \mathrm{mU} / \mathrm{kg} / \mathrm{min}$ insulin.

\section{ANALYSES}

Blood from all subjects was centrifuged promptly and the plasma separated within five minutes after withdrawal. After the precipitation of antibody bound insulin by $25 \%$ polyethylene glycol $^{3}$ diabetic plasma was stored at $-20^{\circ} \mathrm{C}$ for subsequent assay of free insulin, with a double antibody method whose interassay coefficient of variation was $16 \%$.

To obtain comparative data from diabetics and controls plasma from controls was assayed in the same manner for "free" insulin. Diabetic plasma, untreated with polyethylene glycol, was also stored at $-20^{\circ} \mathrm{C}$ for subsequent measure of total insulin by the same radioimmunoassay method after an acid separation step. ${ }^{4}$ Biosynthetic human insulin and bovine insulin standards were employed for the assay of plasma biosynthetic human insulin and bovine insulin concentrations, respectively, and were treated with polyethylene glycol in a similar manner to plasma samples.

The binding of biosynthetic human insulin and bovine insulin labelled with iodine- 125 by fasting serum samples obtained on the morning of each study was determined by a method using polyethylene glycol. ${ }^{5}$ Results were expressed as percentages of labelled insulin bound. For the diabetics an independent measure of antibody bound insulin $(\mathrm{mU} / \mathrm{l})$ was obtained by subtracting the mean free from mean total insulin concentrations during the second euglycaemic hour of the infusion with insulin $1 \mathrm{mU} / \mathrm{kg} / \mathrm{min}$.

Total concentrations of glycosylated haemoglobin were measured by an electrophoretic technique. ${ }^{6}$ The normal range in our laboratory is $5 \cdot 5-7 \cdot 9 \%$

The metabolic clearance rate of insulin was calculated from the constant infusion rate divided by the plasma free insulin concentration. Insulin's pharmacological half life $\left(t \frac{1}{2}\right)$ was determined by fitting quadratic regression lines to the logarithms of the values at 0 , five, 10 , 15 , and 20 minutes. The resulting estimates of slope $b$ at time 0 were converted to half lives by the formula $t \frac{1}{2}=-\log _{10} 2 / b$ (except in three cases where the initial slope was positive and thus no estimate of half life could be made). Combined estimates of half life for the two types of insulin were achieved by averaging the initial slope values from the two experiments and then applying the conversion formula; the average slopes were negative in all cases, allowing valid estimation of average half life for the two insulins. The distribution space of insulin was calculated according to the formula of Gurpide and Mann.?

The initial rate of decline of glucose disposal rate was estimated by fitting quadratic regressions to the values at time 0 and at all subsequent times when data were recorded.

Wilcoxon's rank sum, Wilcoxon's signed ranks, and Kendall's rank correlation tests were used for statistical analyses. Analysis of covariance was used to test the significance of differences between the control and diabetic groups allowing for differences in antibody binding.

Results are expressed as mean (SEM), or as median (range) in the case of some highly skewed variables.

\section{Results}

The mean concentration of glycosylated haemoglobin was significantly greater in the diabetics $(11.6(0.6) \mathrm{g} / \mathrm{dl}$ than in the controls $(6.9(0.3) \mathrm{g} / \mathrm{dl})(\mathrm{p}<0.001)$.

Euglycaemia was achieved after $8.4(2 \cdot 1)$ minutes and $4 \cdot 3(1 \cdot 7)$ minutes of biosynthetic human insulin and bovine insulin infusions, respectively, in controls and $69.7(16.5)$ and $69.7(15.8)$ minutes, respectively, in diabetics. During insulin infusion in controls the mean glucose concentration and coefficient of variation were $3.83(0.10)$ $\mathrm{mmol} / 1(68.9(1.8) \mathrm{mg} / 100 \mathrm{ml})$ and $5.01(0.57) \%$ for biosynthetic human insulin and $3.87(0.08) \mathrm{mmol} / 1(69.7(1.4) \mathrm{mg} / 100 \mathrm{ml})$ and

TABLE II-Comparison of median (range) pharmacokinetics of biosynthetic human insulin (BHI) and bovine insulin (BI) in diabetics and controls. (All differences non-significant)

\begin{tabular}{|c|c|c|c|c|c|c|}
\hline & \multicolumn{2}{|c|}{$\begin{array}{l}\text { Metabolic clearance rate } \\
(\mathrm{ml} / \mathrm{kg} / \mathrm{min})\end{array}$} & \multicolumn{2}{|c|}{$\underset{(\min )}{\text { Plasma half life }}$} & \multicolumn{2}{|c|}{$\underset{(\mathrm{ml} / \mathbf{k g})}{\text { Distribution space }}$} \\
\hline & BHI & BI & BHI & BI & $\mathrm{BHI}$ & BI \\
\hline Diabetics & $\begin{array}{l}13 \cdot 2 \\
(8 \cdot 4-47 \cdot 2)\end{array}$ & $\begin{array}{l}14 \cdot 7 \\
(9 \cdot 1-26 \cdot 2)\end{array}$ & $\begin{array}{l}7 \cdot 8 \\
(2 \cdot 4-*)\end{array}$ & $\begin{array}{l}8 \cdot 7 \\
(2 \cdot 1-*)\end{array}$ & $\begin{array}{l}168 \\
(30-*)\end{array}$ & $\begin{array}{l}195 \\
(29-*)\end{array}$ \\
\hline Controls & $\begin{array}{l}16 \cdot 1 \\
(13 \cdot 2-43 \cdot 5)\end{array}$ & $\begin{array}{l}23 \cdot 9 \\
(9 \cdot 6-52 \cdot 6)\end{array}$ & $\begin{array}{l}3 \cdot 4 \\
(2 \cdot 5-11 \cdot 0)\end{array}$ & $\begin{array}{l}3 \cdot 9 \\
(2 \cdot 7-10 \cdot 7)\end{array}$ & $\begin{array}{l}109 \\
(55-585)\end{array}$ & $\begin{array}{l}162 \\
(39-455)\end{array}$ \\
\hline
\end{tabular}
- In three patients the initial slope, describing the change in free insulin concentration
at the end of the insulin infusion, was positive and no meaningful figure could at the end of the insulin infusion, was positive and
herefore be obtained for half life or distribution space. 
$5.59(0.97) \%$ for bovine insulin. Comparable figures in diabetics were observed for biosynthetic human insulin $(3.88(0.01) \mathrm{mmol} / 1$ (69.8 $(0.18) \mathrm{mg} / 100 \mathrm{ml})$ and $\left.3.99(0.35)^{\circ}{ }_{0}\right)$ and bovine insulin $(3.86(0.02)$ $\mathrm{mmol} / \mathrm{l}(69.5(0.36) \mathrm{mg} / 100 \mathrm{ml})$ and $3.25(0.30) \%)$. During the study of insulin deactivation in controls the mean glucose concentration and coefficient of variation were $3.73(0.09) \mathrm{mmol} / 1(67.1(1.62) \mathrm{mg} /$ $100 \mathrm{ml})$ and $6.54(1.74) \%$ for biosynthetic human insulin and 3.90 $(0.07) \mathrm{mmol} / \mathrm{l}(70.2(1.26) \mathrm{mg} / 100 \mathrm{ml})$ and $5.60(0.78) \%$ for bovine insulin. Comparable figures in diabetics were observed for biosynthetic human insulin $(3.95(0.03) \mathrm{mmol} / 1(71.1(0.54) \mathrm{mg} / 100 \mathrm{ml})$ and $4.62(0.54) \%)$ and bovine insulin $(3.92(0.03) \mathrm{mmol} / 1(70.6(0.54)$ $\mathrm{mg} / 100 \mathrm{ml})$ and $3.93(0.55) \%)$.

\section{INSULIN PHARMACOKINETICS}

Table II shows that no significant differences existed between the pharmacokinetics of biosynthetic human insulin and those of bovine insulin in either the non-diabetic controls or the diabetics. For each subject studied with biosynthetic human insulin and bovine insulin the paired data were therefore averaged to help group comparisons between controls and diabetics.

Figure 1 compares the mean free insulin concentrations in controls and diabetics during and at the end of the infusions of insulin $1 \mathrm{mU}$ / $\mathrm{kg} / \mathrm{min}$. Insulin's median (range) metabolic clearance rate was signi-
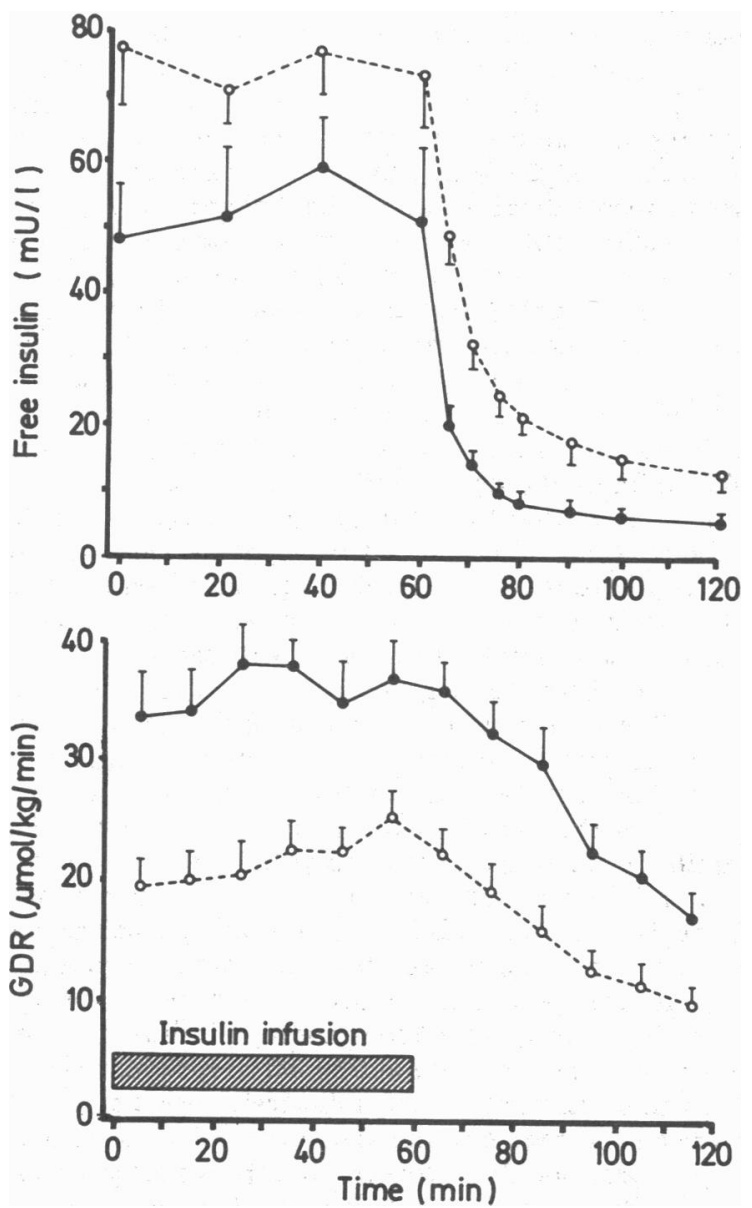

FIG 1-Comparison of mean (SEM) free insulin concentrations and glucose disposal rates (GDR) in 16 diabetics ( $0---0)$ and eight controls ( insulin $1 \mathrm{mU} / \mathrm{kg} / \mathrm{min}$.

Conversion: SI to traditional units-Glucose: $1 \mu \mathrm{mol} \approx 180 \mu \mathrm{g}$.

ficantly greater $(\mathrm{p}<0.05)$ in controls $(19(12-48) \mathrm{ml} / \mathrm{kg} / \mathrm{min})$ than in diabetics $(15(9-34) \mathrm{ml} / \mathrm{kg} / \mathrm{min}$ ) whereas its pharmacological half life was significantly greater $(\mathrm{p}<0.05)$ in diabetics $(7.8(2.7-35.4)$ $\mathrm{min})$ than in controls $(3 \cdot 3(2 \cdot 6-9 \cdot 0) \mathrm{min})$. There was no significant difference in the median distribution space for insulin between controls $(88(45-401) \mathrm{ml} / \mathrm{kg})$ and diabetics $(169(41-1152) \mathrm{ml} / \mathrm{kg})$.
Among the diabetics neither glycosylated haemoglobin concentrations nor daily dose of insulin correlated significantly with insulin's metabolic clearance rate, distribution space, or pharmacological half life.

\section{INSULIN ACTION}

Constant insulin infusion-There were no significant differences between mean glucose disposal rates in response to biosynthetic human insulin and bovine insulin infusions in controls (38.28 (3.39) and $36.11(2.89) \mu \mathrm{mol}(6.89(0.61)$ and $6.50(0.52) \mathrm{mg}) / \mathrm{kg} / \mathrm{min})$ or in diabetics $(20.72(1.72)$ and $21.89(2.28) \mu \mathrm{mol}(3.73(0.31)$ and 3.94 $(0.41) \mathrm{mg}) / \mathrm{kg} / \mathrm{min})$, and for each subject the paired data were therefore averaged. Figure 1 compares the resulting mean glucose disposal rates of controls and diabetics during the second euglycaemic hour of insulin infusion. For each group of subjects the glucose disposal rate increased by a similar extent during this hour and the increases were similar when comparing the responses to biosynthetic human insulin and bovine insulin infusions. The mean (SEM) glucose disposal rate was significantly greater $(\mathrm{p}<0.01)$ for controls $(37.16(3.06) \mu \mathrm{mol}$ (6.69 $(0.55) \mathrm{mg}) / \mathrm{kg} / \mathrm{min})$ than for diabetics $(21.33(1.83) \mu \mathrm{mol}$ $(3.84(0.329) \mathrm{mg}) / \mathrm{kg} / \mathrm{min})$. There were no significant correlations between mean glucose disposal rate and daily insulin dose $(\tau=-0 \cdot 31)$ or between mean glucose disposal rate and glycosylated haemoglobin concentration $(\tau=-0 \cdot 11)$ in diabetics. There were no significant correlations between mean glucose disposal rate and insulin clearance rate in diabetics $(\tau=-0 \cdot 19)$ or in controls $(\tau=-0 \cdot 21)$.

Insulin deactivation-At the end of the insulin infusion the rate of decline in glucose disposal rate was similar after biosynthetic human insulin and bovine infusion in controls (383.3 (44.4) and 488.8 (66.7) nmol (69 (8) and $88(12) \mu \mathrm{g}) / \mathrm{kg} / \mathrm{min}^{2}$ respectively) and diabetics $\left(438.8(72 \cdot 2)\right.$ and $327 \cdot 7(66 \cdot 7) \mathrm{nmol}(79(13)$ and $59(12) \mu \mathrm{g}) / \mathrm{kg} / \mathrm{min}^{2}$ ), and again the paired data were averaged. Figure 1 compares the mean declines in glucose disposal rate at the end of the insulin infusions. There was no significant difference in the initial rate of decline in glucose disposal rate between controls $(433.3(50 \cdot 0) \mathrm{nmol}(78(9) \mu \mathrm{g}) /$ $\left.\mathrm{kg} / \mathrm{min}^{2}\right)$ and diabetics $\left(383.3(61 \cdot 1) \mathrm{nmol}(69(11) \mu \mathrm{g}) / \mathrm{kg} / \mathrm{min}^{2}\right)$. There was no significant relation between the rate of decline in glucose disposal rate and the preceding mean glucose disposal rate during the insulin infusion in diabetics $(\tau=-0.33)$ or controls $(\tau=-0.50)$.

Insulin antibody binding-Mean antibody binding of biosynthetic human insulin $(20.0(3.37) \%)$ was similar to that of bovine insulin $(22.3(3.05) \%)$ in fasting serum samples obtained from the diabetics. Mean antibody bound insulin during the $1 \mathrm{mU} / \mathrm{kg} / \mathrm{min}$ infusion of biosynthetic human insulin $(1755(524) \mathrm{mU} / \mathrm{l})$ was similar to during that of bovine insulin (1983 (615) $\mathrm{mU} / \mathrm{l})$. Agreement was close between the two measures of insulin antibody binding $(\tau=0.71 ; p<0.001)$ when paired data for binding of biosynthetic human insulin and bovine insulin were averaged. In controls mean (SEM) antibody binding was $3 \cdot 0(0 \cdot 1) \%$, with similar binding values for biosynthetic human insulin and bovine insulin.

Table III shows the significant correlations between antibody bound insulin and pharmacokinetic characteristics of insulin, where each subject's paired data for biosynthetic human insulin and bovine insulin have been averaged. Similar values were obtained using the alternative measure of insulin antibody binding. ${ }^{5}$ Thus it appears that increased antibody binding is associated with prolongation of insulin's pharmacological half life and an increase in insulin's metabolic clearance rate and distribution space.

TABLE III-Correlations ( $\tau)$ between measures of insulin antibody and insulin pharmacokinetic characteristics in diabetics

\begin{tabular}{lcc}
\hline & Insulin antibody binding & Antibody bound insulin \\
\hline Pharmacological half life & $+0.71(\mathrm{p}<0.001)$ & $+0.73(\mathrm{p}<0.001)$ \\
Metabolic clearance rate & $+0.55(\mathrm{p}<0.01)$ & $+0.48(\mathrm{p}<0.01)$ \\
Distribution space & $+0.71(\mathrm{p}<0.001)$ & $+0.70(\mathrm{p}<0.001)$ \\
\hline
\end{tabular}

By extrapolating the regression lines describing the correlations between insulin antibody binding (\%) and the reciprocal of insulin's metabolic clearance rate or of insulin's distribution space (fig 2) we can consider whether the derived clearance rate and distribution space of insulin in controls differed from those expected in diabetics with the same low antibody concentrations. Analysis of covariance showed that these differences were significant for clearance rate $(t=$ $4.23 ; 21 \mathrm{df} ; \mathrm{p}<0.001)$ but not for distribution space $(t=1.96)$ or 
insulin's half life $(t=0 \cdot 46)$. Thus it appears that diabetics without insulin antibody binding would be expected to have a reduced insulin clearance rate when compared with non-diabetic controls.

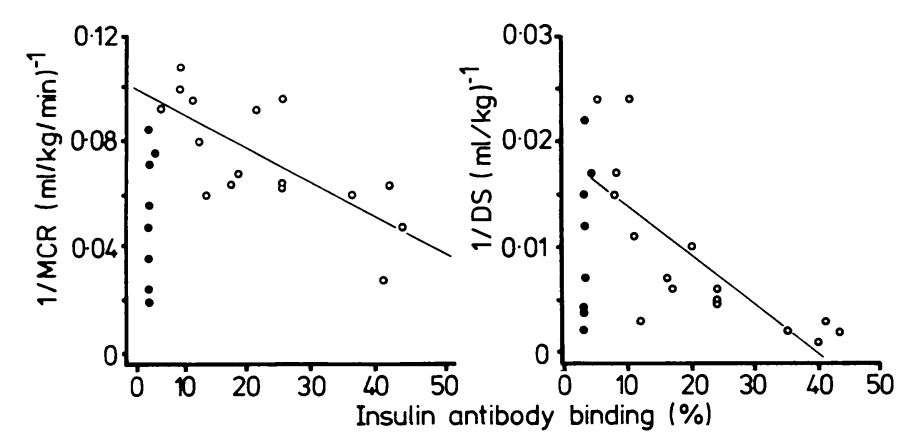

FIG 2-Relations between insulin antibody binding in controls $(O)$ and diabetics $(O)$ and (left) 1 /metabolic clearance rate (MCR) for diabetics: $y=$ $0 \cdot 100-0.00124 \times(\mathrm{p}<0.01)$ and (right) $1 /$ distribution space (DS) (for diabetics: $\mathrm{y}=0.0183-0.00045 \mathrm{x}(\mathrm{p}<0.01))$.

Conversion: SI to traditional units-Glucose: $1 \mu \mathrm{mol} \approx 180 \mu \mathrm{g}$.

No significant relation $(\tau=-0 \cdot 28)$ was observed between glucose disposal rate and insulin antibody binding when paired results for biosynthetic human insulin and bovine insulin studies in diabetics were averaged (fig 3). The mean glucose disposal rate of controls was significantly higher $(t=2.70 ; 21 \mathrm{df} ; \mathrm{p}<0.05)$ than that of diabetics expected at control antibody concentrations.

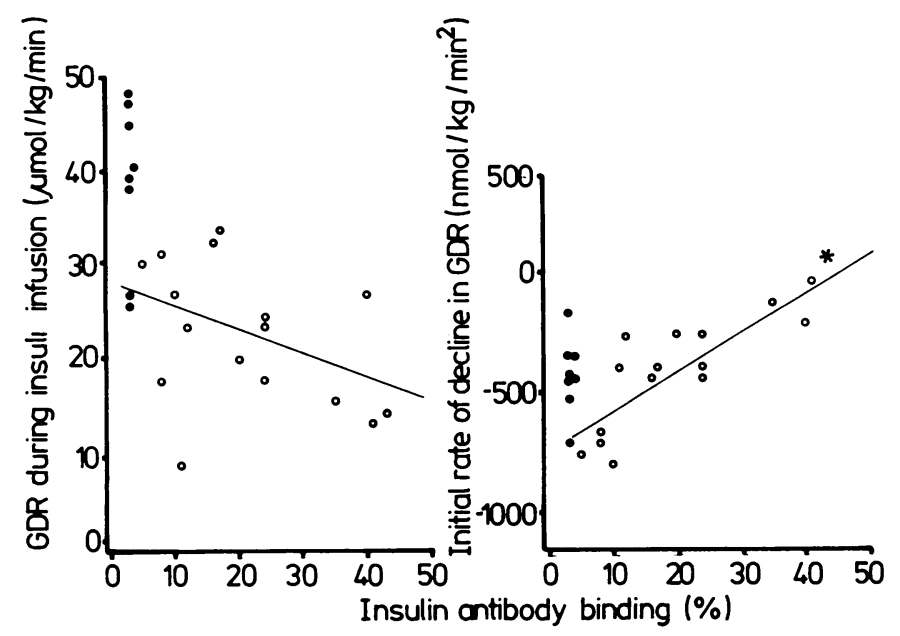

FIG 3-A Relation between insulin antibody binding in controls ( $O$ ) and diabetics $(O)$ and (left) glucose disposal rate (for diabetics: $y=26 \cdot 27-0 \cdot 234 x$ (NS)) and (right) initial rate of decline in glucose disposal rate, at the end of the insulin infusion, (for diabetics: $y=-739+16.8 x(p<0.001)$ ).

*A diabetic whose glucose disposal rate had not appreciably fallen two hours after the end of the insulin infusion.

A significant correlation $(\tau=0.62 ; p<0.001)$ was observed between initial rate of decline in glucose disposal rate, rate of decline at the end of the insulin infusion, and insulin antibody binding, when paired results from biosynthetic human insulin and bovine insulin studies in diabetics were averaged (fig 3 ). The initial rate of decline in glucose disposal rate in controls was significantly less than that extrapolated from the diabetics with the same low antibody concentrations ( $t=$ $3 \cdot 16 ; 21 \mathrm{df} ; \mathrm{p}<0.01$ ).

A significant correlation $(\tau=0.70 ; p<0.001)$ was observed between initial rate of decline in glucose disposal rate and insulin's half life in diabetics but not in controls $(\tau=0.00)$.

There were no significant correlations between insulin antibody binding and daily insulin dose or glycosylated haemoglobin concentration.

\section{Discussion}

In vitro assessment of insulin's bioactivity and binding to specific cell receptors shows human and animal insulins to be indistinguishable. ${ }^{8}$ In vivo comparisons of human and pork, ${ }^{9} 10$ or human and beef, ${ }^{11}$ insulin actions in healthy volunteers have, with few exceptions, ${ }^{12}{ }^{13}$ emphasised the similarities in bioactivities of insulins derived from differing species. Conversely, insulin treated diabetics have been reported by some workers to exhibit enhanced sensitivity to pork by comparison with beef insulin, ${ }^{14}$ and this difference has been attributed to the increased binding affinity of circulating antibodies to beef rather than pork insulin. ${ }^{14}{ }^{15}$ By contrast, we have failed to show any difference in the antibody binding of beef and human insulins in diabetics previously immunised with beef or pork insulin, or both. As expected, therefore, we have shown that the pharmacokinetics of beef and human insulins are indistinguishable in such patients and that their biological actions, in respect of glucose disposal, are also similar.

Preliminary assessment of the influence of insulin antibodies on the pharmacokinetics of intravenously injected insulin depended on the technique of a single injection of radiolabelled insulin, ${ }^{16}$ which may not behave as native insulin. ${ }^{17}$ The present study, using a constant infusion technique and unlabelled insulin, illustrates the profound influence of such antibodies to prolong the pharmacological half life, increase the distribution space, and hasten the metabolic clearance rate of insulin, with the result that insulin's pharmacokinetics are quite different in immunised diabetics and non-immunised non-diabetics. It appears possible that insulin treated diabetics of long standing without insulin antibodies clear insulin from plasma more slowly than non-diabetic controls. This phenomenon may occur as a function of duration of diabetes or insulin treatment as diabetics treated with insulin for three months, having minimal antibody binding, show a normal insulin clearance rate. ${ }^{18}$ Whatever else, it seems clear that an understanding of insulin kinetics in non-diabetics need have little bearing on the kinetics of insulin in longstanding, insulin treated diabetics.

It is now recognised that many longstanding, insulin dependent diabetics are insulin resistant. ${ }^{19} 20$ The present study shows that this insulin resistance is unrelated to the presence of insulin antibodies when insulin action is assessed under steady state conditions. This observation accords with the failure to show a direct relation between daily insulin dose and insulin antibody binding. ${ }^{21}$ Thus despite insulin antibodies being shown to prevent insulin receptor interaction ${ }^{22}$ and our own findings showing that antibodies increase insulin's clearance rate no significant correlation was observed between glucose disposal rate and insulin antibody binding. Presumably, individual variation in insulin sensitivity was sufficient to obscure any such relation if, indeed, it exists. It should also be noted that we failed to confirm antibody induced enhancement of insulin action, consequent to receptor self aggregation, as has been shown in vitro. ${ }^{23}$

Our results confirm that longstanding, insulin treated diabetics with or without insulin antibodies are, nevertheless, profoundly insulin resistant. Such insulin resistance may be a function of prevailing degree of metabolic control ${ }^{24}$ and is reported by some, ${ }^{25}{ }^{26}$ but not all, ${ }^{20}$ workers to improve after a period of optimised control. Insulin resistance would appear to develop as a function of duration of diabetes as diabetics treated with insulin for a short term-that is, three months-show normal insulin action. ${ }^{18}$ It is tempting to speculate that the insulin resistance and disturbance of insulin clearance and distribution in longstanding, insulin treated patients may be interrelated, as has been described in other states of more extreme resistance. ${ }^{27}$

The presence of insulin antibodies clearly prolongs the biological half life of insulin. Indeed, in one patient with particularly high levels of insulin binding the glucose disposal rate had not appreciably diminished two hours after stopping the intravenous insulin infusion. When accompanying severe steady state insulin resistance this phenomenon might be expected to be associated with the unfortunate combination of postprandial 
hyperglycaemia and nocturnal hypoglycaemia. ${ }^{28}$ Alternatively, a small number of reports imply that benefit accrues from the presence of insulin antibodies, particularly in patients receiving single daily insulin doses, ${ }^{29}$ when insulin action is presumably prolonged to the patient's advantage. Our findings complement those of Vaughan et al, who concluded that antibodies, acting as carrier proteins, may sustain free insulin concentrations and retard the rate of development of hyperglycaemia or ketosis after withdrawal of insulin. ${ }^{30}$ Figure 3 shows that in diabetics without antibodies insulin action is lost more rapidly, at the end of the insulin infusion, than in non-diabetics. As such, it is theoretically possible that the ability of antibodies to sustain insulin action may be advantageous to all diabetics without endogenous insulin secretion. There is currently no evidence that the absence of insulin antibody binding is beneficial to glycaemic control. The alternative view remains that insulin antibodies may be harmful in other respects. ${ }^{31-33}$

We thank Ms A Munro for secretarial help; Professor K G M M Alberti and Ian Hanning for help in establishing a radioimmunoassay for free and total insulin; and Dr A B Kurtz for help in establishing a measure of insulin antibody binding. This work was funded by grants from the Scottish Hospital Endowments Research Trust (SHERT 632) and the Wellcome Foundation.

Biosynthetic human insulin, radiolabelled biosynthetic human insulin and bovine insulin, and unlabelled biosynthetic human insulin and bovine insulin standards were supplied by Eli Lilly, USA, and bovine insulin by the Wellcome Foundation. Twenty per cent human serum albumin was donated by the Edinburgh and South east Scotland Regional Blood Transfusion Service.

\section{References}

1 Gray RS, Scarlett JA, Griffin J, Olefsky JM, Kolterman OG. In vivo deactivation of peripheral, hepatic and pancreatic insulin action in man. Diabetes $1982 ; 31$. 929-36.

2 Doberne L, Greenfield MS, Schulz B, Reaven GM. Enhanced glucose utilization during prolonged glucose clamp studies. Diabetes 1981;30:829-35.

Nagakawa S, Nakayama H, Sasaki T, et al. A simple method for the determination

4 Soeldner J, Slone D. Critical variables in the radioimmunoassay of serum insulin using the double antibody technic. Diabetes $1965 ; 14: 771-9$.

5 Kurtz AB, Matthews JA, Mustaffa BE, Daggett PR, Nabarro JDN. Decrease of antibodies to insulin, proinsulin and contaminating hormones after changin treatment from conventional beef to purified pork insulin. Diabetologia 1980

6 Read A, Tibi L, Smith AF. Assessment of a simple electrophoretic method for measuring HbA1. Clin Chim Acta 1980;108:487-91.

7 Gurpide E, Mann J. Interpretation of isotopic data obtained from blood-borne compounds. 7 Clin Endocrinol Metab 1970;30:707-18. Sonnenberg GE, Berger $M$. Human insulin: much ado about one amino acid.
Diabetologia 1983;25:457-9.
9 Adeniyi-Jones ROC, Jones RH, Barnes DG, Gerlis LS, Sonksen P. Porcine and human insulin (Novo): a comparison of their metabolism and hypoglycaemic activity in normal man. Diabetes Care 1983;6 (suppl 1): 9-12.

GAA, Hanning I, Alberti KGMM, Owens DR. A comparison of the activity and disposal of semisynthetic human and porcine insulin in normal man by the glucose clamp technique Diabetologio 1982;22:41-5.

, Cowan P, Duncan LJP, Clarke BF. A comparison of the biological actions and pharmacokinetics of intravenously infused highly purified beef and

12 Kiosynthetic human insulins in normal man. Diabete Metab 1984;10:188-93. DNA technolo A, Pickup JC, et al. Human insulin produced by recombinant 1980;ii:398-401.

13 Chisholm DJ, Kraegen EW, Hewett MJ, Lazarus L. Comparison of potency of porcine insulin and semisynthetic human insulin at 3 dose levels using the euglycaemic clamp. Horm Metab Res 1983;15:415-8.

14 Asplin CM, Hartog M, Goldie DJ. Change of insulin dosage, circulating free and bound insulin and insulin antibodies on transferring diabetics from conventional to highly purified porcine insulin. Diabetologia 1978;14:99-105

15 Kurtz AB, Matthews JA, Nabarro JDN. Insulin-binding antibody: reaction differences with bovine and porcine insulins. Diabetologia 1978;15:19-22. inger $\mathrm{RE}$, Morris $\mathrm{JH}$, McKnight FG, Diederich DA. Disappearance of $\mathrm{I}^{131}$ 1964;270:767-70.

17 Orskov H, Christensen NB. Plasma disappearance rate of injected human insulin in juvenile diabetic, maturity-onset diabetic and non-diabetic subjects.

Diabetes $1969 ; 18: 653-9$.
18 Gray RS, Cowan P, Clarke BF, Duncan LJP. Insulin resistance in type 1 diabetes reversed by conventional insulin treatment. In: De Pirro R, ed. Proceedings of the 2nd International Symposium on Insulin Receptors. Rome: Tipografica Ambro-
sini, 1983:104.

9 De Fronzo RA, Hendler R, Simonsen D. Insulin resistance is a prominent feature of insulin-dependent diabetes. Diabetes 1982;31:795-801.

等 type 1 i57:904-10.

21 Asplin CM, Hartog M, Goldie DJ. The relationship between circulating free and bound insulin, insulin antibodies, insulin dosage and diabetic control in insulin treated diabetics. Acta Endocrinol 1978;87:330-8.

22 De Pirro R, Fusco A, Spallone L, Magnatta R, Lavro R. Insulin antibodies prevent insulin-receptor interactions. Diabetologia 1980;19:118-22.

23 Schechter Y, Chang KJ, Jacobs S, Cuatrecasas P. Modulation of binding and bioactivity of insulin by anti-insulin antibody: relation to possible role of receptor self-aggregation in hormone action. Proc Natl Acad Sci USA 1979;76:2720-4 insulin resistance in controlled insulin-dependent, type 1 , diabetic patients. $\mathcal{f}$ Clin Endocrinol Metab 1984;58:353-8.

25 Lager I, Lonnroth P, Von Schenk H, Smith U. Reversal of insulin resistance in type 1 diabetes after treatment with continuous subcutaneous insulin infusion. $\mathrm{Br}$ Med $\mathcal{F} 1983 ; 287: 1661-4$.

26 Yki-Jarvinen H, Koivisto VA. Continuous subcutaneous insulin infusion therapy decreases insulin resistance in type 1 diabetes. F Clin Endocrinol Metab 1984; 58:659-66.

27 Flier JS, Minaker K, Landsberg L, Young JB, Pallota J, Rose JW. Impaired in vivo insulin clearance in patients with severe target-cell resistance to insulin. (1)

28 Harwood R. Insulin binding antibodies and "spontaneous" hypoglycemia. $N$ Engl

29 Gray RS, Borsey DQ, Kurtz A, et al. Relationship of glycosylated haemoglobin to C-peptide secreting status and antibody binding of insulin in insulin-dependent
diabetes. Horm Metab Res 1981;13:599-603. V Vaughan NJA, Matthews JA, Kurtz AB, Nabarro JDN. The bioavailability of circulating antibody-bound insulin following insulin withdrawal in type 1 (insulin-dependent) diabetes. Diabetologia 1983;24:355-8.

31 Fallucca $F$, Iavicoli $M$, Russo $A$, et al. IgG insulin-antibodies in the fetus of a diabetic mother. In: Pinchera A, Fenzi GF, Baschieri L, Doniach D, eds. Autoimmune aspects of endocrine disorders. New York: Academic Press, 1981:307-10. 32 Anderson $\mathrm{OO}$. Anti-insulin antibodies and late diabetic complications. Acto Endocrinol $1975 ; 83: 329-40$ Reeves WG, Allen BR, Tattersall RB. Insulin-induced lipoatrophy : evidence for

(Accepted 20 February 1985)

100 YEARS AGO

A protest ought to be made against the loose and inaccurate way in which measurements are often guessed at, in medical and especially in surgical writings. We have long been accustomed to read of the tumour which was about the size of a fotal head, or a hen's egg, or a Tangerine orange, or a millet-seed, and we have all endeavoured to form some working average of the size of this miscellaneous series; so too, it is not uncommon to read that an ulcer is about the size of a sixpenny-bit, or half-a-crown. Of late years, however, since the florin has come into more general use, ulcers also seem to have become smaller. We have grown so accustomed to this most unscientific system, that we have almost ceased to remember how bad it is; but when we find other nations following our bad habit, we at once perceive its inconveniences. In a recent number of one of the principal medical journals published in the United States of America, two trivial comparisons occur which leave the average European reader quite in the dark. In one case we are told that a certain tumour of the thumb was "altogether about as large as a butter-nut," and that in another case the slough was "about the size of a quarter-dollar." Now, what do these comparisons convey to the average English reader? As to the quarter-dollar, he has perhaps a hazy vision of a coin rather smaller than a shilling; but the butter-nut, we imagine, conveys no more precise idea to his mind than the famous "piece of chalk," or to use the comparisons in vogue on this side of the Atlantic, the tumour might have had any size between a "fotal head" and a "Barcelona-nut." (British Medical fournal 1885;i:1115.)

Not the least of the advantages which we gain from our connection with the Colonies, is that of participation in their practically inexhaustible foodsupply. It is a fact of the best omen for the mother-country and for them that, in a time of general commercial torpor and need of economy, meat, the best and costliest form of necessary food, is to be had at two-thirds, or even half, of the price at which it has hitherto been sold in the British market. At various parts of the metropolis, frozen mutton or lamb from Australia, and beef from America, of excellent quality, are now being sold at this low rate. The meat is well preserved, fresh, and usually succulent and tender, though we have observed about some of the mutton a certain density, which is perhaps due to its previous contraction by freezing. This, however, is a small evil, and by no means sufficient to discount in any marked degree the value of the meat as nutriment, or even to mar its agreeable flavour. The care with which the freezing process is carried out appears in the freshness of the meat when thawed, a freshness which is not quickly lost. These facts ought to speak in favour of the imported beef and mutton, which come not at all too soon in the interest of all classes, of the poor especially, but not of the poor alone. A short time ago, a suggestion appeared in one of the evening papers, that the abundant meat-produce of the Colonies might thus be utilised to feed the army at Suakin. It would certainly seem that, so long, at least, as the army can be easily reached from its base at the coast, it is not likely to find in the flesh-pots of Egypt better provision than that which we have here briefly described. (British Medical fournal 1885;i:1118.) 